\title{
Management of Abdominal Surgery of Patients with Sickle-Cell Anaemia
}

\author{
Ugur Topal ${ }^{1}$, Ahmet Gokhan Saritas², Abdullah Ulku³ , Atilgan Tolga Akcam \\ 1, 2, 3, 4 Department of General Surgery, Cukurova University, Adana, Turkey.
}

\section{ABSTRACT}

\section{BACKGROUND}

Sickle cell anaemia (SCA) is one of the most common haemoglobinopathies in the world. In patients with SCA, cholecystectomy and splenectomy are the most common abdominal operations. In this study, we aimed to review the management of abdominal surgery in patients with SCA.

\section{METHODS}

This is a retrospective study. SCA patients who underwent abdominal surgery between June 2011 and June 2018 were included in our study. Demographic characteristics, preoperative and postoperative hematological parameters, details of the operations, peroperative management, postoperative complications and their management were examined.

\section{RESULTS}

We performed our study on operated SCA $(n=15)$ patients. $67 \%(n=10)$ of the patients were male. The age distribution of the patients was $32.8 \pm 13.8(18-61)$ the patients' indications for operation were $73.3 \%(n=11)$ cholelithiasis $6.7 \%(n=$ 1) spleen infarction $13.3 \%(n=2)$ hypersplenism and $6.7 \%(n=1)$ cholelithiasis + hypersplenism. Laparoscopic cholecystectomy $(\mathrm{n}=9)$ laparoscopic splenectomy $(\mathrm{n}=1)$ cholecystectomy $(\mathrm{n}=1)$ cholecystectomy + splenectomy $(n=1)$ cholecystectomy + choledochoduodenostomy $(n=1)$ were the surgical operations performed on the patients. Preoperative blood counts showed haemoglobin (Hgb) (g / dL) $9.52 \pm 1.44$ (6.1 - 11.1); hematocrit (Htc) $\% 28.6 \pm 5.42$ (17.2 - 34.4) Haemoglobin S percentage (HbS) $55 \pm 24$ (29 - 95). Since 7 patients had $\mathrm{HbS}$ over $40 \%$ preop exchange transfusion was performed. Haemoglobin S percentage (HbS) after exchange transfusion was $23 \pm 7.2$ (12 - 33) preoperative erythrocyte replacement was $1.13 \pm 1.3(0-4)$. Postoperative blood counts showed; Haemoglobin (Hgb) (g / dL) $9.4 \pm 1.08$ (7.1 - 11.4); hematocrit (htc) $28 \% \pm 4.3(21-37.6)$. The total duration of hospital stay was $11.2 \pm 4.05(5-21)$ days; postoperative duration of stay was $4.6 \pm 2.16(2-10)$ days. Postoperative surgical complications were $6.7 \%(\mathrm{n}=1)$ wound infection and $\% 6.7(\mathrm{n}=1)$ acute renal failure developed. Postoperative hematologic complications were $6.7 \%(\mathrm{n}=$ 1) developed vaso-occlusive crisis $6.7 \%(n=1)$ developed hemolytic crisis. No patients developed mortality.

\section{CONCLUSIONS}

Patients with SCA have a relatively high risk for postoperative complications. A multidisciplinary approach including hematologist, surgeon and anesthesiologist is required in the surgical management of SCA.

\section{KEY WORDS}

Sickle Cell Anaemia, Cholelithiasis, Postoperative Management.
Corresponding Author: Dr. Uğur Topal,

Department of General Surgery, Cukurova University,

Faculty of Medicine, Adana, Turkey. E-mail: sutopal2005@hotmail.com

DOI: $10.14260 /$ jemds $/ 2021 / 25$

How to Cite This Article:

Topal U, Saritas $A G$, Ulku A, et al. Management of abdominal surgery of patients with Sickle-cell anaemia. J Evolution Med Dent Sci 2021;10(03):118122, DOI: $10.14260 / \mathrm{jemds} / 2021 / 25$

Submission 06-09-2020,

Peer Review 18-11-2020,

Acceptance 25-11-2020,

Published 18-01-2021.

Copyright (C) 2021 Ugur Topal et al. This is an open access article distributed under Creative Commons Attribution License [Attribution 4.0 International (CC BY 4.0)] 


\section{BACKGROUND}

Sickle cell anaemia is one of the most common haemoglobinopathies in the world. SCA disease is frequently encountered in Asia, India, Middle East, Africa, South and Central America and in the Mediterranean region of our country. The general incidence of being an SCA carrier is between $0.3-0.6 \%$ in Turkey while especially in some areas in the Mediterranean region this frequency can reach $3-44$ $\% .^{1}$

SCA occurs when valine is replaced with glutamic acid at position 6 of the amino acid sequence representing one of the globin chains of the haemoglobin molecule based on a single gene mutation. In this autosomal recessive disease, the term SCA is used for the patients carrying haemoglobin S in a homozygous state while the presentation of people carrying haemoglobin $\mathrm{S}$ along with other haemoglobins is defined as sickle syndromes. ${ }^{2}$ The disease is characterized by red cells undergoing sickling due to polymerization of sickle haemoglobin ( $\mathrm{Hb}-\mathrm{S})$ when deoxygenated with subsequent loss of flexibility and repeated hemolysis with microvascular occlusion. ${ }^{3}$

The most common abdominal surgical operations performed on patients with SCA are cholecystectomy and splenectomy. Cholecystectomy is frequently performed in patients with SCA because of gallbladder stones. ${ }^{4}$ In patients with SCA there is an increase in the risk of pigment gallstones due to chronic hemolysis and $50-85 \%$ of patients have gallstones. ${ }^{5}$ Historically surgical procedures in sickle cell patients have been associated with relatively increased risks of perioperative mortality vaso-occlusive (painful) crisis acute chest syndrome post-operative infections and congestive heart failure. Careful preoperative assessment and judicious peri-operative management are critical in mitigating these risks. In this study we aimed to review surgical management in 15 patients with SCA who underwent abdominal surgery.

\section{METHODS}

This was a retrospective study, SCA patients who underwent abdominal surgery between June 2011 and June 2018 in Cukurova University were included in our study. A common database was created by examining patient files and hospital information system records. Patient information was evaluated retrospectively. This work has been carried out in accordance with the Declaration of Helsinki (2000) of the World Medical Association. Before the operation patients were informed in detail about the operation.

Demographic characteristics, Body Mass Index (BMI) values, comorbidities, indications, type of surgery performed, preoperative complete blood counts, preoperative haemoglobin $\mathrm{S}$ percentages, whether exchange transfusion was performed or not, post-exchange haemoglobin $S$ percentage in patients who received exchange transfusion, how many units of RBC was used for exchange transfusion, preoperative transfusion amount and preoperative hydration information were evaluated. Haemoglobin S level lower than $30 \%$ and haemoglobin level around $10 \mathrm{~g} / \mathrm{dL}$ was targeted in patients before the surgery. The total duration of hospital stay, duration of hospitalization after surgery, duration of the operation and the amount of haemorrhage during operation were recorded. Postoperative transfusion was evaluated with a complete blood count at the 12th postoperative hour. Postoperative surgical and haematological complications, analgesic treatment regimen used in the postoperative period and hospital re-admission rates of the first 90 days were evaluated.

\section{Statistical Analysis}

Statistical analysis was performed using IBM SPSS Statistics for Windows version 24 (IBM Corp. Armonk N.Y. USA). Values were given as mean \pm Standard Deviation (SD) and minimummaximum.

\section{RESULTS}

We performed our study on operated SCA (n: 15) patients. 67 $\%(n=10)$ of the patients were male and $33 \%(n=5)$ were female. The age distribution of the patients was $32.8 \pm 13.8$ (18 - 61) BMI was $22.7 \pm 3.1$ (17.9 - 29). As concomitant disease 2 cases had hypertension 1 case had chronic kidney disease 1 case had heart failure 1 case had venous insufficiency 1 case had hypothyroidism 1 case had autoimmune haemolytic anaemia and 1 case had $B$ thalassemia. The operation indications were $73.3 \%(n=11)$ cholelithiasis $6.7 \%(n=1)$ spleen infarction $13.3 \%(n=2)$ hypersplenism and $6.7 \%(\mathrm{n}=1)$ cholelithiasis + hypersplenism. The surgical treatments performed were laparoscopic cholecystectomy $(\mathrm{n}=9)$ laparoscopic splenectomy $(\mathrm{n}=1)$ cholecystectomy $(\mathrm{n}=1)$ cholecystectomy + splenectomy $(\mathrm{n}=1)$ cholecystectomy + choledochoduodenostomy $(n=1)$ (Table 1$)$.

\begin{tabular}{|c|c|c|}
\hline \multirow{2}{*}{\multicolumn{3}{|c|}{$\begin{array}{cc}\text { Parameter } & \text { N: } 15(\%) \\
\text { Demographic Characteristics (Mean } \pm \text { SD Distribution) }\end{array}$}} \\
\hline & & \\
\hline \multirow{4}{*}{ Sex } & Male & 10 (66.7 \%) \\
\hline & Female & $5(33.3 \%)$ \\
\hline & Median Age & $32.8 \pm 13.8(18-61)$ \\
\hline & BMI & $22.7 \pm 3.1(17.9-29)$ \\
\hline \multirow{7}{*}{ Comorbidity } & Hypertension & $2(13.2)$ \\
\hline & Chronic kidney disease & $1(6.7)$ \\
\hline & Heart failure & $1(6.7)$ \\
\hline & Venous insufficiency & $1(6.7)$ \\
\hline & Hypothyroidism & $1(6.7)$ \\
\hline & Autoimmune haemolytic anaemia & $1(6.7)$ \\
\hline & B thalassemia & $1(6.7)$ \\
\hline \multirow{4}{*}{ Indication } & Cholelithiasis & $11(73.3)$ \\
\hline & Hypersplenism & $2(13.2)$ \\
\hline & Spleen infarcts & $1(6.7)$ \\
\hline & Cholelithiasis + Hypersplenism & $1(6.7)$ \\
\hline \multirow{6}{*}{$\begin{array}{l}\text { Applied } \\
\text { Surgical } \\
\text { Treatment }\end{array}$} & Laparoscopic cholecystectomy & $9(60)$ \\
\hline & Splenectomy & $2(13.2)$ \\
\hline & Laparoscopic splenectomy & $1(6.7)$ \\
\hline & Cholecystectomy & $1(6.7)$ \\
\hline & Cholecystectomy + Splenectomy & $1(6.7)$ \\
\hline & $\begin{array}{l}\text { Cholecystectomy + } \\
\text { Choledochoduodenostomy }\end{array}$ & $1(6.7)$ \\
\hline \multicolumn{3}{|c|}{$\begin{array}{l}\text { Table 1. Demographic Characteristics of the Patients Their } \\
\text { Comorbidities, Indication and Applied Surgery }\end{array}$} \\
\hline
\end{tabular}

The preoperative blood counts of the patients in our study showed WBC $\left(\mathrm{mm}^{3}\right)$ as $11.56 \pm 9.15(5-43.4)$; haemoglobin (Hgb) (g / dL) $9.52 \pm 1.44$ (6.1 - 11.1); 
haematocrit $(\mathrm{Htc}) \% 28.6 \pm 5.42$ (17.2 - 34.4); platelet (Plt) $\left(\mathrm{mm}^{3}\right) 329.000 \pm 198.000$ (47000 - 796000); Haemoglobin S percentage (HbS) $55 \pm 24$ (29 - 95). Since 7 patients had HbS over $40 \%$. preop exchange transfusion was performed. Haemoglobin S percentage (HbS) after exchange transfusion was $23 \pm 7.2$ (12 - 33). Preoperative erythrocyte replacement was $1.13 \pm 1.3(0-4)$. The patients were hydrated preoperatively with balanced saline (SF $0.09+$ Dex $5 \%$ ). Mean hydration level was $2.3 \pm 0.7$ (1 - 3.5) L (Table 2).

\begin{tabular}{|cc|}
\hline White Blood Count / $\mathrm{mm}^{3}$ & $11.56 \pm 9.15(5-43.4)$ \\
Haemoglobin (Hgb) / (g / dL) & $9.52 \pm 1.44(6.1-11.1)$ \\
Hematocrit (Htc) & $\% 28.6 \pm 5.42(17.2-34.4)$ \\
Platelet (Plt) / mm & $329 \pm 198(47-796)$ \\
Haemoglobin S percentage (HbS) & $55 \pm 24(29-95)$ \\
After exchange transfusion (HbS) & $23 \pm 7.2(12-33)$ \\
Preoperative erythrocyte replacement / unit & $1.13 \pm 1.3(0-4)$ \\
Preoperative hydration & $2.3 \pm 0.7(1-3.5)$ \\
(Saline \% 0.09 + Dextrose \%5) L & \\
\hline Table 2. Preoperative Laboratory Characteristics of the Patients \\
(Mean \pm SD distribution)
\end{tabular}

Postoperative blood counts showed; WBC $\left(\mathrm{mm}^{3}\right) 16.70 \pm$ 7.4 (1.6 - 29.2); Haemoglobin (Hgb) (g / dL) $9.4 \pm 1.08$ (7.111.4); haematocrit (Htc) $28 \% \pm 4.3$ (21 - 37.6); platelets (Plt) $\left(\mathrm{mm}^{3}\right) 308.000 \pm 160.000(24000-658000)$ (Table 3).

\begin{tabular}{|cc|}
\hline White Blood Count $/ \mathrm{mm}^{3}$ & $16.70 \pm 7.4(1.6-29.2)$ \\
Haemoglobin $(\mathrm{Hb})(\mathrm{g} / \mathrm{dL})$ & $9.4 \pm 1.08(7.1-11.4)$ \\
Haematocrit $(\mathrm{Htc})$ & $\% 28 \pm 4.3(21-37.6)$ \\
Platelet (Plt) $/ \mathrm{mm}^{3}$ & $308 \pm 160(24-658)$ \\
\hline Table 3. Postoperative Laboratory Characteristics \\
of the Patients (Mean \pm SD)
\end{tabular}

\begin{tabular}{|c|c|c|}
\hline \multirow{4}{*}{ Operation Details } & Total hospitalisation duration / day & $\begin{array}{c}11.2 \pm 4.05 \\
(5-21)\end{array}$ \\
\hline & Postoperative hospitalisation duration / day & $\begin{array}{l}4.6 \pm 2.16 \\
(2-10)\end{array}$ \\
\hline & Operation duration / $\min$ & $\begin{array}{c}90 \pm 34 \\
(60-165)\end{array}$ \\
\hline & Intraoperative bleeding amount / $\mathrm{mL}$ & $\begin{array}{c}81 \pm 68 \\
(20-300)\end{array}$ \\
\hline \multirow{3}{*}{$\begin{array}{l}\text { Postoperative } \\
\text { Analgesics }\end{array}$} & Tramadol HCl 100 mg / mL 3*1: & $8(53.3)$ \\
\hline & Diclofenac sodium $75 \mathrm{mg} \mathrm{3*1}$ & $5(33.3)$ \\
\hline & Tramadol HCl 100 + Paracetamol 500 mg 3*1 & $2(13.4)$ \\
\hline \multirow{2}{*}{ Morbidity } & Wound site infection & $1(6.7)$ \\
\hline & Acute kidney failure & $1(6.7)$ \\
\hline \multirow{3}{*}{$\begin{array}{l}\text { Postoperative } \\
\text { Haematological } \\
\text { Complication }\end{array}$} & Vaso occlusive crisis & $1(6.7)$ \\
\hline & Hemolytic crisis & $1(6.7)$ \\
\hline & Paralytic ILEUS & $1(6.7)$ \\
\hline $\begin{array}{l}\text { 90-day re- } \\
\text { admission }\end{array}$ & Hematoma at wound site & $1(6.7)$ \\
\hline \multicolumn{3}{|c|}{$\begin{array}{l}\text { Table 4. Intraoperative and Postoperative } \\
\text { Clinical Characteristics of the Patients }(\text { Mean } \pm S D)\end{array}$} \\
\hline
\end{tabular}

The total duration of hospital stay for the patients was $11.2 \pm 4.05$ (5 - 21) days; postoperative duration of stay was $4.6 \pm 2.16(2-10)$ days. The duration of operation was $90 \pm$ 34 (60 - 165) minutes; intraoperative bleeding amount was $81 \pm 68(20-300) \mathrm{ml}$. Postoperative analgesia was performed in 8 patients with tramadol $\mathrm{HCl} 100 \mathrm{MG} / \mathrm{ML} 3 * 1$ in 5 patients with diclofenac sodium $75 \mathrm{mg} 3 * 1$ and in 2 patients with tramadol $\mathrm{HCl} 100+$ paracetamol $500 \mathrm{mg} 3 * 1$. When we looked at postoperative surgical complications $6.7 \%(\mathrm{n}=1)$ wound infection and \% $6.7(\mathrm{n}=1)$ acute renal failure developed. When we looked at the postoperative haematological complications $6.7 \%(\mathrm{n}=1)$ developed vasoocclusive crisis $6.7 \%(\mathrm{n}=1)$ developed haemolytic crisis. No patients developed mortality. When we looked at the 90-day readmission $6.7 \%(n=1)$ presented with ileus and $6.7 \%(n=$ 1) presented with haematoma at the wound site (Table 4 ).

\section{DISCUSSION}

Patients with sickle cell anaemia have increased postoperative morbidity. The most common causes of morbidity are vaso-occlusive crisis, haemolytic crisis, acute chest syndrome, infections and congestive heart failure. In some studies, the morbidity rate is reported as $12-34 \%{ }^{6,7}$ In our study postoperative haematological complication rate was $13.4 \%$ and surgical complication rate was $13.4 \%$.

Major stress factors in the development of complications in patients with SCA are; surgical and anaesthetic applications, potential hypotension, hypoxia, acidosis, hypoperfusion and hypothermia. ${ }^{4}$ The most common abdominal surgical interventions in patients with SCA are cholecystectomy and splenectomy. Although it is difficult to determine the true incidence of cholelithiasis in patients with SCA, most patients develop gallbladder stones with advanced age. Some studies in the literature indicate that the incidence of cholelithiasis varies between 8 - $55 \%$ in patients with SCA and the incidence increases with age. In accordance with this the most common abdominal surgical intervention in patients with sickle cell anaemia have become cholecystectomy. ${ }^{4,8,9}$ In patients with SCA the most common abdominal surgery after cholecystectomy is a splenectomy. Primary indications are hypersplenism, recurrent sequestration crises, splenic infarcts and abscesses. ${ }^{2}$ The indications for splenectomy in our study were hypersplenism and splenic infarction. In the literature cholecystectomy is also recommended in patients with gallbladder stones determined during splenectomy for patients with SCA. Concomitant cholecystectomy will eliminate the subsequent complications of gallbladder stone without increasing morbidity. ${ }^{10}$ Three patients who underwent splenectomy had a history of cholecystectomy. One patient underwent simultaneous cholecystectomy performed by our team. When evaluated in terms of aetiology; the group with the highest risk of infection after a splenectomy is haematological diseases. As a rule, pneumococcal and $H$. influenza type $\mathrm{b}$ conjugate vaccines should be given at least two weeks before splenectomy in cases of splenectomy under elective conditions. Although the efficacy and protection of immunization after splenectomy is reported to be low in the literature it is recommended that vaccines should be administered within two weeks after emergency splenectomy. The importance of vaccination prior to splenectomy increases with the increase in the duration of hospitalisation due to increased susceptibility to encapsulated bacteria after a splenectomy and the serious economic burden of the medications used.11,12 All patients who underwent splenectomy were vaccinated in the preoperative period.

In patients with SCA the factors that may cause vasoocclusive crisis should be closely monitored in the preoperative intraoperative and postoperative periods and perioperative measures should be taken to prevent them. Management protocols including preoperative exchange transfusion should be developed. Patients with SCA should undergo a preoperative clinical evaluation. The preoperative sickle cell genotype, the frequency of crisis, the last crisis history, the duration of hospital stay during the painful crisis, triggering causes for the crisis, opioid use, steady state 
haemoglobin level, haematocrit, reticulocyte, WBC count and history of blood transfusion should be evaluated.

In order to reduce postoperative complications minimally invasive procedures should be preferred when surgical intervention is needed in patients with SCA. Laparoscopic cholecystectomy and splenectomy are more preferred than open cholecystectomy and splenectomy in patients with SCA. Laparoscopic intervention in many centres is associated with a significant reduction in postoperative complications. ${ }^{13,14}$ In our study $66 \%$ of the operations were performed with minimally invasive techniques.

Close follow-up of haematological parameters is required in patients with SCA. Complete blood count before and after the operation and preoperative haemoglobin electrophoresis should be performed. Preoperative haemoglobin (Hgb) should be kept at around $10 \mathrm{~g} / \mathrm{dL}$ and $\mathrm{HbS}$ level below $40 \%$. If necessary, blood transfusion and exchange transfusion should be performed to achieve these values. There are studies in the literature suggesting that lowering preoperative $\mathrm{HbS}$ level to $30 \%$ and below decreases postoperative morbidity and mortality.9,15 There are also studies showing that keeping the haemoglobin $\mathrm{S}$ level below $30 \%$ and haemoglobin level around 10 gr / dL with conservative transfusion instead of exchange transfusion does not have an advantage. 4,6 When the studies in the literature are examined there is no consensus about preoperative transfusion. The preoperative tests of the patients included in our study showed that the Hgb level was $9.52 \mathrm{Hb} \mathrm{S}$ was $55 \%$. Therefore, exchange transfusion was applied to 7 patients and an average of 1.13 units of erythrocyte replacement was performed.

Fluid replacement in patients with SCA is important to reduce the morbidity that may occur. Preoperative hydration should be performed and continued until the postoperative oral feeding period. Excessive fluid overload should be avoided as it may cause heart failure, acute chest syndrome and pulmonary oedema. The amount of fluid therapy that should be applied is conflicted in the literature. ${ }^{16}$ The amount of hydration to be applied should be individualized according to the patient, pre-operative cardiac examination should be performed and if necessary cardiac reserve should be determined by echocardiography. We hydrated the patients in our study with an average of $2.3 \mathrm{~L}$ of water.

Several factors should be considered in the management of patients with SCA. Peroperative emotional stress status of the patients is one of them. Emotional stress can trigger a haemolytic crisis and anxiolytics should be used if necessary. ${ }^{17}$

In the literature the mean duration of operation in series with cholecystectomy and splenectomy was $72 \mathrm{~min} .{ }^{18}$ In our series the mean operation time was 90 minutes, and this result was close to the literature. Intraoperative careful hemostasis in patients with SCA is important to prevent postoperative morbidities. In our series the mean intraoperative bleeding amount was $80 \mathrm{~mL}$. There was no significant decrease in haemoglobin levels in postoperative hematological examinations. In the literature the mean duration of hospitalization in patients with SCA who underwent abdominal surgery was 7.4 days and 5.4 days of those were in the postoperative period. ${ }^{18}$ In our study the mean duration of hospitalization was 11.2 days and the postoperative hospital stay was 4.6 days. The higher total duration of hospitalization than the literature was thought to be related to the waiting duration in the patients with exchange transfusion. A multidisciplinary approach involving the haematologist, surgeon and anesthesiologist is required in the surgical management of SCA. During operation hypoxia, hypothermia and acidosis should be prevented and oxygenation should be monitored continuously. Postoperative nasal oxygen administration should be continued.

Postoperative analgesic treatment of patients is an important issue to be considered. Since SCA patients are exposed to opioids, they often tend to acquire opioid tolerance and require large doses. The main opioid agonists used in the postoperative period were morphine and hydromorphone. Alternatively, patient-controlled continuous pain management can be used. In addition to pharmacological pain management, non-pharmacological measures may be added. Relaxation heat or ice packs and even music can be used for this purpose. ${ }^{19}$ In the management of pain in our study; 10 patients were treated with narcotic analgesics and 5 patients with Non-Steroid Anti-Inflammatory Drugs (NSAID).

The limitations of our study were its retrospective nature and the limited number of patients. Despite these limitations in our study, we wanted to present our experience in the management of abdominal surgery in patients with SCA in accordance with our own practice.

\section{CONCLUSIONS}

In our study, we wanted to present our experience in the management of abdominal surgery in patients with SCA in accordance with our own practice. Patients with SCA have a relatively high risk for postoperative complications. A multidisciplinary approach including hematologist, surgeon and anesthesiologist is required in the surgical management of SCA.

Data sharing statement provided by the authors is available with the full text of this article at jemds.com.

Financial or other competing interests: None.

Disclosure forms provided by the authors are available with the full text of this article at jemds.com.

The study was approved by the local Institutional Review Board. Dated 01.02.2019 numbered 85/57.

\section{REFERENCES}

[1] Ünal S, Balcı YI, Toprak SK, et al. Eritrosit hastaliklari ve haemoglobin bozuklukları tani ve tedavi klavuzu. Türk Hematoloji Derneği 2011;1:53-66.

[2] Al-Salem AH. Splenic complications of sickle cell anaemia and the role of splenectomy. ISRN Hematol 2011;2011:864257.

[3] Meshikhes AW. Towards safer surgery in patients with sickle cell disease. Saudi Med J 2007;28(12):1788-90.

[4] Acipayam C. Preoperative and postoperatıve management in children with sickle cell anaemia undergoing surgery: a single-center experience. Kocatepe Medical Journal 2017;8:44-8. 
[5] Cameron JL, Maddrey WC, Zuidema GD. Biliary tract disease in sickle cell anaemia: surgical considerations. Ann Surg 1971;174(4):702-10.

[6] Vichinsky EP, Haberkern CM, Neumayr L, et al. A comparison of conservative and aggressive transfusion regimens in the perioperative management of sickle cell disease. The preoperative transfusion in sickle cell disease study group. N Engl J Med 1995;333(4):206-13.

[7] Buck J, Davies SC. Surgery in sickle cell disease. Hematol Oncol Clin North Am 2005;19(5):897-902.

[8] Issa $\mathrm{H}$, Al-Salem AH. Role of ERCP in the era of laparoscopic cholecystectomy for the evaluation of choledocholithiasis in sickle cell anaemia. World J Gastroenterol 2011;17(14):1844-7.

[9] Bhattacharyya N, Wayne AS, Kevy SV, et al. Perioprtaive management for cholecystectomy in sickle cell disease. J Pediatr Surg 1993;28(1):72-5.

[10] Al-Salem AH. Indications and complications of splenectomy for children with sickle cell disease. J Pediatr Surg 2006;41(11):1909-15.

[11] Görkem M, Atay M H, Kelkitli E, et al. Splenectomy in haematological diseases-single center experience. J Exp Clin Med 2012;29(4):276-9.

[12] Davies JM, Barnes R, Milligan D, et al. Update of guidelines for the prevention and treatment of infection in patients with an absent or dysfunctional spleen. Clin Med (Lond) 2002;2(5):440-3.
[13] Tagge EP, Othersen HB, Jackson SM, et al. Impact of laparoscopic cholecystectomy on the management of cholelithiasis in children with sickle cell disease. J Pediatr Surg 1994;29(2):209-12.

[14] Al-Mulhim AS, Al-Mulhim AA. Laparoscopic cholecystectomy in 427 adults with sickle cell disease: a single-center experience. Surg Endosc 2009;23(7):1599602.

[15] Ware R, Filston HC, Schultz WH, et al. Elective cholecystectomy in children with sickle haemoglobinopathies. Successful outcome using a preoperative transfusion regimen. Ann Surg 1988;208(1):17-22.

[16] Jones J, Quinn R. Fluid replacement strategies in sickle cell disease. Proceedings of UCLA Healthcare 2017;21:13.

[17] Adjepong KO, Otegbeye F, Adjepong YA. Perioperative management of sickle cell disease. Mediterr J Hematol Infect Dis 2018;10(1):e2018032.

[18] Al-Salem AH, Qaiseruddin S, Naserulla Z. Perioperative management of children with sickle cell disease undergoing major abdominal surgery. Saudi Med J 2002;23(10):1294-96.

[19] Yawn BP, Buchanan GR, Afenyi-Annan AN, et al. Management of sickle cell disease: summary of the 2014 evidence-based report by expert panel members. JAMA 2014;312(10):1033-48. 